\title{
PENGARUH OPINI GOING CONCERN, PERGANTIAN MANAJEMEN, KESULITAN KEUANGAN, DAN REPUTASI AUDITOR PADA AUDITOR SWITCHING
}

\author{
Cokorda Krisna Yudha ${ }^{1}$ \\ Ni Ketut Rasmini ${ }^{2}$ \\ Made Gede Wirakusuma ${ }^{3}$
}

${ }^{1}$ Fakultas Ekonomi dan Bisnis Universitas Udayana, Bali, Indonesia e-mail: yudhacokkrisna@yahoo.com

${ }^{2}$ Fakultas Ekonomi dan Bisnis Universitas Udayana, Bali, Indonesia

${ }^{3}$ Fakultas Ekonomi dan Bisnis Universitas Udayana, Bali, Indonesia

\begin{abstract}
ABSTRAK
Penelitian ini bertujuan untuk menganalisis pengaruh opini going concern, pergantian manajemen, kesulitan keuangan dan reputasi auditor pada auditor switching serta menguji perbedaan pengaruh opini going concern, pergantian manajemen, kesulitan keuangan dan reputasi auditor pada auditor switching antara perusahaan berukuran besar, sedang dan kecil. Data penelitian dikumpulkan dari perusahaan manufaktur terbuka (Tbk) yang terdaftar di BEI. Jumlah pengamatan sejumlah 368 observasi dari tahun 2013-2015. Metode analisis menggunakan uji regresi logistik dan uji beda koefisien regresi. Hasil studi menunjukkan bahwa terdapat pengaruh kesulitan keuangan dan reputasi auditor terhadap auditorswitching. Namun opini going concern dan pergantian manajemen tidak berpengaruh terhadap auditor switching. Hasil penelitian juga menyimpulkan bahwa terdapat perbedaan pengaruh opini going concern, pergantian manajemen, kesulitan keuangan dan reputasi auditor pada auditor switching antara perusahaan besar dan kecil.
\end{abstract}

Kata kunci: auditor switching, opini going concern, pergantian manajemen, kesulitan keuangan, reputasi auditor

\begin{abstract}
This study aims to analyze the effect of goingconcern opinions, managementchange, financial distress and auditor reputation in the auditor switching as well as to examine differences in the effect of goingconcern opinions, managementchange, financial distress and auditor reputation on auditors switching between large, medium and small enterprises. The research data were collected from open manufacturing enterprises (Tbk) listed on the ISE. The number of observations was368 observations from 2013-2015.The method of analysis used logistic regression test and test of regression coefficient difference. The results of the study indicated that there was an effect of financial distress and the auditor reputation on the auditor switching. However, goingconcern opinions and managementchange would not affect auditorsswitching. The results also concluded that there were differences in the effect of goingconcern opinions, managementchange, financial distress and auditors reputation at auditors switching between large and small enterprises.

Keywords: auditor switching, going-concern opinions, management change, financial distress, auditor reputation
\end{abstract}




\section{PENDAHULUAN}

Laporan keuangan adalah sarana pertanggungjawaban (stewardship) dari manajemen terhadap pemilik perusahaan. Selain pemilik perusahaan dan manajemen, informasi laporan keuangan digunakan oleh pihak ketiga sebagai pertimbangan dalam pengambilan keputusan.Akuntan publik memiliki tanggung jawabdalam opini yang diberikan terkait dengan kewajaran laporan keuangan yang disusun oleh pihak manajemen.

Berdasarkan Standar Audit (SA) 700, bentuk opini dibagi menjadi dua kategori yaitu opini tanpa modifikasian bila Auditor menyimpulkan bahwa laporan keuangan disusun, dalam semua hal yang material, sesuai dengan kerangka pelaporan keuangan yang berlaku, serta opini modifikasian SA 705 jika Auditor menyimpulkan bahwa, berdasarkan bukti audit yang diperoleh, laporan keuangan secara keseluruhan tidak bebas dari kesalahan penyajian material, atau tidak dapat memperoleh bukti audit yang cukup dan tepat untuk menyimpulkan bahwa laporan keuangan secara keseluruhan bebas dari kesalahan penyajian material. Tentunya manajemen mengharapkan akuntan publik memberikan penilaian atau opini wajar tanpa pengecualian, biasanya opini wajar dengan pengecualian, pendapat tidak wajar, dan tidak menyatakan pendapat, tidak diharapkan oleh manajemen dan pengguna lainnya. Pihak manajemen berupaya agar tidak memperoleh opini wajar dengan pengecualian karena dapat menentukan tinggi rendahnya harga saham perusahaan dan insentif yang diperoleh oleh manajer (Chow dan Rice 1982). Peneliti lain yaitu Carcello dan Neal (2003) menyatakan, auditor memiliki keyakinan potensi diganti menjadi lebih besar jika 
menerbitkan opini going concern, yaitu opini yang diterbitkan oleh auditor jika terdapat kemungkinanyang cukup tinggi terkait dengan kelangsungan hidup suatu usahadalam periode yang ditentukan. Sehingga dalam hal ini peran auditor sebagai pihak yang diharapkan memiliki sikap independensi sangat diuji.

Skandal di Indonesia yang melibatkan auditor yaitu pada perusahaan PT. Kimia Farma yang pada saat itu diaudit oleh KAP Hans Tuanakkota dan Mustofa (HTM) pada tahun 2001, kemudian PT.Kereta Api Indonesia (PT. KAI) yang diaudit oleh KAP. S Manan pada tahun 2005 merupakan kasus manipulasi laporan keuangan yang dilakukan oleh manajemen dan ketidakmampuan KAP dalam mengindikasi terjadinya manipulasi. Skandal yang terjadi menimbulkan kesangsian dari masyarakat terhadap profesi akuntan dengan alasan bahwa implikasi tersebut menyebabkan KAP besar melanggar objektivitas, independensi, dan integritasyang tinggi. Fakta tersebut menjadi salah satu pertimbangan bagi perusahaan untuk mengambil tindakan auditor switching, karena opini yang diterima oleh perusahaan tidak sesuai dengan ekspektasi manajemen (Tandirerung, 2006) dan auditor dianggap tidak bekerjasama. Perusahaan kemudian mempertimbangkan untuk menunjuk KAP baru yang dianggap dapat bekerjasama (Ardana dkk, 2008).

Terdapat beberapa perusahaan di Indonesia yang melakukan pergantian auditor (auditor switching) secara sukarela (voluntary) diantaranya:PT. Ekploitasi Energi Indonesia pada tahun 2011 sampai dengan 2015 berturut-turut di audit oleh KAP Hendrawinata Hendri \& Siddharta, KAP Mulyamin Sensi Suryanto \& Lianny, KAP Gideonadi \& Rekan, KAP Hendrawinata Hendri Siddharta \& 
Tanzil, KAP Hendrawinata Hendri Siddharta \& Tanzil. PT. Alam Karya Unggul pada tahun 2011 sampai dengan 2015 berturut-turut di audit oleh KAP Hadiwinata \& Rekan, KAP Budiman Wawan Pamudji \& Rekan, Mulyamin Sensi Suryanto \& Lianny, KAP Mulyamin Sensi Suryanto \& Lianny, kemudian pada tahun 2015 perusahaan tersebut mengalami delisting. PT. Pasific Strategic Financial pada tahun 2011 sampai dengan 2015 berturut-turut di audit oleh KAP Drs. Imam Safei \& Rekan, Drs. Imam Safei \& Rekan, KAP Achmad Rasyid Hisbullah \& Rekan, KAP Achmad Rasyid Hisbullah \& Rekan, dan pada tahun 2015 di audit oleh KAP Warnoyo (www.idx.co.id, 2015).

Fenomena terjadinya pergantian auditor yang dilakukan oleh perusahaan, pergantian auditor sering kali dilakukan sebelum masa perikatan yang disyaratkan oleh PMK. Hal tersebut didasarkan adanya faktor berupa opini going concern, kesulitan keuangan, pergantian manajemen, ukuran perusahaan, serta reputasi auditor. Dalam penelitian ini adapun faktor-faktor yang diangkat yaitu pergantian manajemen, opini going concern, reputasi auditordan kesulitan keuangan.

Motivasi penelitian adalah melakukan pengujian kembali faktor determinan yang dianggap dapat menentukan terjadinya auditor switching yang digunakan dalam penelitian terdahulu, dengan alasan hasil penelitian sebelumnya menyimpulkan inkonsistensi hasil penelitian(research gap). Inkonsistensi pertama berasal dari inkonsistensi perspektif. Inkonsistensi penelitian dapat dilihat bahwa terdapat penelitian terdahulu yang membahas auditor switching berpengaruh terhadap opini audit (going concern) (Mustofa, 2010; Diyanti, 2010) sedangkan 
penelitian lainnya membahas mengenai opini yang berpengaruh terhadap pergantian auditor (Chow \& Rice, 1982; Rahayu, 2012). Inkonsistensi perspektif penelitian tersebut memotivasi peneliti untuk meneliti pengaruh opini going concern terhadap auditor switching dengan dasar pemikiran bahwa setelah opini going concern dikeluarkan maka opini tersebut menjadi dasar pertimbangan untuk melakukan auditor switching. Inkonsistensi yang kedua berasal dari inkonsistensi hasil. Chow dan Rice (1982) yang membuktikan bahwa qualified opinion berpengaruh positif terhadap auditor switching, hasil yang serupa ditemukan oleh Damayanti dan Sudarma (2006) serta Rahayu (2012) yang menyimpulkan bahwa opini going concern berpengaruh signifikan terhadap auditor switching. Namun, hasil penelitian yang berbeda ditemukan oleh Sinarwati (2010) yang membuktikan bahwa going concern opinion dan auditor reputation tidak berpengaruh signifikan terhadap auditor changes, namun demikian management changes dan financial distress berpengaruh signifikan terhadap auditor switching.

Motivasi kedua, dilihat dari pengukuran kesulitan keuangan. Mayoritas pengukuran kesulitan keuangan menggunakan leverage sebagai proksi dari kesulitan keuangan dengan pertimbangan perusahaan yang memiliki leverage yang tinggi mengindikasikan perusahaan tersebut berada dalam kondisi kesulitan keuangan (Damayanti dan Sudarma, 2006; Sinarwati, 2010; Rahayu; 2012). Namun demikian, belum terdapat cut off nilai leverage yang pasti dapat menunjukkan perusahaan berada dalam kondisi kesulitan keuangan. Penelitian ini menggunakan pendekatan Altman Z-Score untuk menilai apakah perusahaan tersebut berada dalam kesulitan keuangan atau tidak. Pertimbangan menggunakan 
Altman Z-Score karena memiliki nilai cut off yang pasti dalam menempatkan apakah perusahaan tersebut berada dalam kesulitan keuangan atau tidak.

Motivasi ketiga, menambahkan ukuran perusahaan ke dalam penelitian. Penelitian mengenai pergantian auditor sudah cukup banyak dilakukan namun dalam penelitian ini mempertimbangkan ukuran perusahaan. Nasser et al. (2006) dan Sinarwati (2011) melakukan pengujian terhadap ukuran perusahaan terhadap pergantian auditor. Namun kedua penelitian tersebut menempatkan ukuran perusahaan sebagai variabel bebas. Penelitian ini bermaksud menguji adanya indikasi bahwa terjadinya auditor switching berbeda antara perusahaan besar, sedang dan kecil dengan menggunakan ukuran perusahaan sebagai cut off pengujian. Dengan demikian, diduga terdapat perbedaan pengaruh pergantian manajemen, opini going concern, reputasi auditor dan kesulitan keuangan pada auditor switching antara perusahaan berukuran besar, sedang, dan kecil.

Teori yang mendasari penelitian ini adalah agency theory.Teori keagenan yang ditemukan oleh Jensen dan Meckling (1976) mendeskripsikan hubungan antara agen (agency relationship) sebagai relasi yang terjadi karena kemungkinan adanya perjanjian yang diaplikasikan antara principal yang menggunakan pihak manajemen untuk melaksanakan usaha yang dimiliki oleh principal. Jensen dan Meckling (1976) menyimpulkan permasalahan agensi dipicu karena perbedaan kepentingan dan informasi antara agent (manajemen) dan principle (pemegang saham). Perbedaan pandangan antara pemilik dan agent terjadi dengan alasan bahwa agent berpotensi tidak selalu mengikuti arahan dari principal, sehingga adanya kemungkinan terjadinya biaya keagenan (agency cost). Teori agensi 
menjelaskan bahwa auditor dianggap pihak yang dapat menyelesaikan konflik perbedaan pendapat antara pihak principal dengan pihak agent. Perbedaan pandangan tersebut sering kali menimbulkan terjadinya konflik, implikasi dari terjadinya konflik tersebut lebih sering merujuk pada pergantian manajemen dan manajemen yang baru cenderung melakukan pergantian auditor.

Melumad dan Ziv (1997) menyimpulkan bahwa perusahaan yang memperoleh opini going concern berimplikasi pada perubahan harga saham yang cenderung negatif yang kemudian akan berdampak pada dilakukannya pergantian auditor oleh manajemen dengan alasan bahwa auditor mengeluarkan opini going concern. Ramadhany (2004) membuktikan bahwa pada perusahaan yang dalam kondisi keuangan yang tidak sehat sering kali ditemukan permasalahan going concern. Menurut Carcello dan Niel (2003), manajemen berniat mengganti auditornya atas konsekuensi opini yang tidak diinginkan oleh perusahaan atas kewajaran laporan keuangannya. Pernyataan tersebut mendapat dukungan dari penelitian yang dilakukan oleh Santi Rahayu (2012) yang mendapatkan pengaruh signifikan dari opini going concern terhadap auditor switching.

Uraian teori agensi menunjukkan bahwa manajemen sebagai pihak yang dianggap memiliki keperluan pribadi yang kemudian berkeinginan memaksimalkan keperluannya. Pihak manajemen ingin memastikan bahwa opini yang diperoleh sesuai dengan keperluannya agar dapat mendapatkan dana dari investor baru. Dengan kekuasaan yang dimiliki maka manajemen dengan mudah melakukan pengambilan keputusan dalam menentukan auditor yang diinginkan. Keputusan pergantian auditor dilakukan karena manajemen berharap dengan 
menunjuk auditor baru, perusahaan dapat menemukan auditor yang mempunyai pandangan yang memiliki satu visi. Berdasarkan teori dan hasil penelitian sebelumnya, maka rumusan hipotesis sebagai berikut:

$\mathrm{H}_{1}$ : Opini going concernberpengaruh positif padaauditor switching.

Wijayani dan Januarti (2011) membuktikan fenomena terjadinya pergantian manajemen diikuti dengan kemungkinan terjadinya auditor switching. Damayanti (2008) dan Nagi (2005) menyimpulkan bahwa pergantian manajemen biasanya akan terjadi pergantian di beberapa aspek seperti perubahan kebijakan dalam akuntansi, keuangan, pemilihan KAP. Perusahaan berupaya mengganti KAP yang lama dan menunjuk KAP baru yang dianggap sesuai dengan kebijakan dan pelaporan akuntansi. Firth (1999) mengungkapkan bahwa pergantian manajemen yang berada di posisi puncak berpotensi menimbulkan terjadinya pergantian audit Big 8 daripada non Big 8 . Berdasar pada teori agensi, kondisi tersebut terjadi dengan alasan bahwa manajemen adalah pihak yang memiliki kepentingan pribadi. Berdasarkan teori dan hasil penelitian sebelumnya, maka rumusan hipotesis sebagai berikut:

$\mathrm{H}_{2}$ : Pergantian manajemenberpengaruh positif padaauditor switching.

Kesulitan keuangan merupakan kondisi dimana kondisi keuangan perusahaan berada dalam situasi yang tidak sehat dalam artian bahwa kondisi keuangan perusahaanberpotensi mengalami kebangkrutan atau kolaps. Kebangkrutan adalah situasi perusahaan yang tidak dapat memenuhi kewajibannya segera. Schwartz et. al. (1995) membuktikan bahwa perusahaan yang dalam posisi kesulitan keuangan berpotensi menutup usahanya cenderung 
melakukan pergantian KAP, karena kesulitan melakukan pembayaran fee audit. Damayanti dan Sudarma (2008) menyebutkan ada motivasi yang tinggi dalam berupaya melakukan pergantian auditor pada perusahaan yang berpotensi bangkrut. Sinarwati (2011) dan Nasser et al. (2006) menyimpulkan adanya hubungan positif antara leverage dan permintaan audit dengan auditor yang memiliki brand name auditors. Berdasarkan hasil penelitian sebelumnya, maka rumusan hipotesis sebagai berikut:

$\mathrm{H}_{3}$ : Kesulitan keuangan berpengaruh positif padaauditor switching

Halim (1997) menyimpulkan bahwa perusahaan berupaya mencari KAP yang memiliki tingkat kredibilitas yang tinggi untuk meningkatkan perspektif positif di mata di mata pemakai laporan keuangan. Crasswell et. al (1998) berpendapat bahwa klien memiliki sudut pandang bahwa auditor yang berasal dari KAP yang memiliki skala audit yang besar dan didukung dengan afiliasi dengan KAP Big 4 memiliki tingkatan objektif yang lebih tinggi karena auditor tersebut memiliki ciri-ciri yang dikaitkan dengan kualitas melalui proses pelatihan, pengakuan international, serta adanya peer review. Fillani dan Yenni (2012), menemukan pengaruh yang signifikan dari reputasi auditor terhadap pergantian KAP. Berdasarkan hasil penelitian sebelumnya, maka rumusan hipotesis sebagai berikut:

$\mathrm{H}_{4}$ : Reputasi auditor berpengaruh negatif padaauditor switching.

Setelah menyimpulkan terdapat pengaruh opini going concern pada auditor switching, untuk selanjutnya dilakukan pembuktian yang lebih spesifik guna mendukung peran opini going concern pada auditor switching. Opini going 
concern cenderung lebih sering diberikan kepada perusahaan dengan skala kecil dengan alasan auditor memiliki keyakinan bahwa kesulitan keuangan di perusahaan besar lebih mudah untuk dicarikan jalan keluarnya dibandingkan kesulitan keuangan yang terjadi pada perusahaan kecil (Mutchler, 1985 dalam Alexander, 2004). Ramadhany (2004) menyimpulkan bahwa fee audit yang tinggi diberikan oleh perusahaan yang skala usahanya lebih besar dibandingkan dengan yang diajukan oleh perusahaan yang skala bisnisny lebih kecil. Fee audit memiliki pengaruh signifikan sehingga auditor berpotensi ragu dalam memberikan opini going concern ke perusahaan besar. McKeown et al.(1991) menyimpulkan perusahaan besar memiliki kemungkinan lebih rendah dalam menjalankan bisnis yang gagal dalam menajalankan operasional usahanya.

Perusahaan dengan ukuran yang lebih besar memiliki akses yang lebih besar untuk mendapatkan sumber dana dari setiap sumber, menyebabkan untuk mendapatkan pinjaman dari kreditur pun akan relatif lebih dikarenakan perusahaan dengan skala yang lebih besar mempunyai peluang yang lebih tinggi dalam bertahan di industri (Fitria, 2014). Perusahaan skala besar memiliki kemungkinan yang lebih besar dibandingkan perusahaan kecil dalam menetapkan auditor mereka dengan alasan bahwa manajemen bagian keuangan akan melakukan penelitian terkait dengan pemberhentian auditor sebelum waktu yang ditentukan berdasarkan kontrak (Carcello dan Neal, 2003).

Filanni dan Yenni (2013), menemukan hubungan yang signifikan antara reputasi auditor terhadap pergantian kantor akuntan publik. Hasil tersebut didukung oleh kesimpulan yang ditemukan oleh Hana (2012). Hasil yang berbeda 
didapatkan oleh Rahayu (2012), dalam penelitiannya mendapatkan fakta bahwa reputasi auditor tidak berpengaruh secara signifikan terhadap auditor switching. Monica (2016) menyatakan, auditor yang berafiliasi dengan KAP besar mempunyai kredibilitas yang lebih baik sehingga kualitas mengenai hasil auditnya lebih baik danmenerbitkan opini sesuai dengan keadaan perusahaan. Perusahaan dengan ukuran kecil memiliki potensi lebih besar dalam melakukan pergantian KAP dengan cara melakukan sewa jasa KAP big 4 menjadi KAP non big 4 dengan ekspektasi untuk mengurangi terjadinya biaya keagenan (Suryandari, 2012).

Dengan demikian opini going concern, pergantian manajemen, kesulitan keuangan, dan reputasi auditor antara ukuran perusahaan yang berbeda diprediksi berpengaruh secara berbeda pada auditor switching. Berdasarkan uraian tersebut di atas, maka rumusan hipotesis sebagai berikut:

$\mathrm{H}_{5}$ : Terdapat perbedaan pengaruh opini going concern, pergantian manajemen, kesulitan keuangan, dan reputasi auditor pada auditor switching antara perusahaan berukuran besar, sedang, dan kecil.

\section{METODE PENELITIAN}

Konsep penelitian ini merupakan suatu hubungan ilmiah berdasarkan landasan teoretis yang telah dijelaskan pada bagian sebelumnya. Konsep penelitian ini disajikan pada Gambar 1.

Variabel independen dalam penelitian ini adalah opini going concern, perubahan manajemen, kesulitan keuangan, dan reputasi auditor. Kemudian variabel dependen dalam penelitian ini adalah auditor switching. Pengujian hipotesis 1 (satu) sampai dengan 4 (empat) menggunakan analisis regresi logistik, 
sedangkan pengujian hipotesis 5 (lima) menggunakan uji beda koefisien regresi antara ukuran perusahaan yang memiliki total aset berkategori besar, sedang, dan kecil. Penilaian ukuran perusahaan dapat digolongkan berdasarkan perspektif tinggi rendahnya total aset yang dimiliki (Sinarwati, 2010).

Gambar 1.

Konsep Penelitian

\section{Variabel IndependenVariabel Dependen}

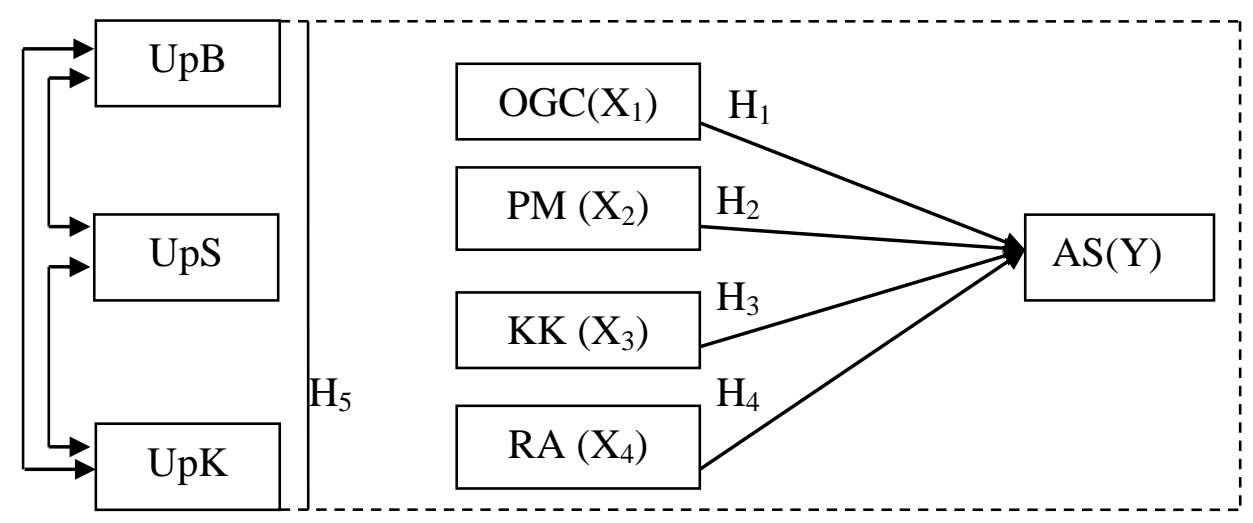

Keterangan:

OGC : Opini Going Concern

PM : Pergantian Manajemen

KK : Kesulitan Keuangan

RA : Reputasi Auditor

AS : Auditor Switching

UpB : Ukuran Perusahaan Besar

UpS : Ukuran Perusahaan Kecil

UpK : Ukuran Perusahaan Sedang

Ukuran perusahaan dianggap memiliki pengaruh terhadap auditor switching karena semakin besar perusahaan berimplikasi pada rumitnya pengaturan usahanya serta terdapat perbedaan menjadi lebih besar antara manajemen dan principal dalam permintaan yang tinggi dalam mengurangi biaya keagenan (Watts dan Zimmerman, 1986). Disamping itu ukuran perusahaan mengalami peningkatan sehingga potensi terjadinya konflik agen juga menjadi 
meningkat berimplikasi pada peningkatan permintaan untuk kualitas audit yang menyebabkan perusahaan akan mencari auditor yang lebih baik.

Lokasi penelitian dilakukan pada Bursa Efek Indonesia (BEI). BEI digunakan sebagai lokasi penelitian dikarenakan BEI adalah tempat atau wadah menyelenggarakan suatu sistem dan sarana untuk mempertemukan penawaran dan permintaan efek dari para pelaku saham dengan tujuan memperdagangkan efek. Selain itu di BEI juga perusahaan melakukan penyampaian informasi mengenai aktivitas perusahaannya.

Penelitian ini menggunakan data sekunder, yaitu data yang diperoleh secara tidak langsung dari objek yang ditelitinya (Sumarsono, 2004). Data yang diperoleh berupa laporan keuangan yang di publikasikan oleh perusahaan yang terdaftar di Bursa Efek Indonesia periode 2013-2015. Data laporan tahunan perusahaan didapat melalui situs $\underline{w w w . i d x . c o . i d a t a u}$ melalui website perusahaan itu sendiri.

Populasi dan sampel dalam penelitian ini adalah perusahaan go public yang merupakan emiten di Bursa Efek Indonesia (BEI) selama periode 20132015. Metode penentuan sampel (sampling method) yang digunakan dalam penelitian ini adalah purposive sampling, yaitu teknik pengambilan sampel dengan pertimbangan atau kriteria tertentu (Sugiyono, 2015:78). Kriteria yang dipertimbangkan dalam pengambilan sampel penelitian ini adalah sebagai berikut.

1) Perusahaan manufaktur yang terdaftar di BEI secara berturut-turut selama periode pengamatan yaitu 2013-2015. Perusahaan manufaktur digunakan dengan alasan bahwa jumlah perusahaan manufaktur merupakan mayoritas 
perusahaan yang terdapat di Bursa Efek Indonesia. Penggunaan industri manufaktur untuk menghindari terjadinya industrial effect, sehingga penelitian ini tidak menggunakan industri keuangan. Dalam industri keuangan, auditor switching tidak dapat dilakukan dengan fleksibel, karena auditor harus berekanan kepada OJK selaku badan pengawas industri keuangan.

2) Perusahaan yang melaporkan laporan keuangannya secara berturut-turut dari tahun 2013-2015. Dasar pemikiran ini adalah agar pengamatan yang dilakukan dapat konsisten selama tahun amatan.

3) Laporan keuangan yang dapat diakses secara lengkap di website IDX atau pada website resmi perusahaan. Beberapa perusahaan yang listing di Bursa Efek Indonesia seringkali tidak mempublikasikan laporan keuangannya di website resmi perusahaan atau di IDX dengan alasan yang bervariasi, seperti adanya perubahan atas laporan keuangan yang diaudit tidak dipublikasikan serta tidak dapat diunduh.

Teknik analisis data yang digunakan adalah regresi logistik karena variabel terikatnya merupakan data kualitatif yang menggunakan variabel dummy (Sumodiningrat, 2001:42). Dalam penelitian ini hipotesis 1 (satu) sampai dengan 4 (empat) diuji dengan regresi logistik. Model regresi logistik yang digunakan adalah

$$
\operatorname{Ln} \frac{\mathrm{P}(\text { SWITCH })}{1-\mathrm{P}(\mathrm{SWITCH})}=\alpha+\beta 1 \mathrm{OGC}+\beta 2 \mathrm{PM}+\beta 3 \mathrm{KK}+\beta 4 \mathrm{RA}+\varepsilon \mathrm{i} \ldots \ldots . .(1)
$$

\section{Keterangan:}




\begin{tabular}{|c|c|}
\hline \\
\hline \multicolumn{2}{|c|}{$\mathrm{P}(\mathrm{SWITCH})-$} \\
\hline \multicolumn{2}{|c|}{ a Konstanta } \\
\hline \multicolumn{2}{|c|}{$\begin{array}{ll}\alpha & : \text { Konstanta } \\
\beta 1-\beta 4 & : \text { Koefisien regresi masing-masing faktor }\end{array}$} \\
\hline \multicolumn{2}{|l|}{ OGC } \\
\hline PM & : Pergantian Manajemen \\
\hline & : Kesulitan Keuangan \\
\hline & : Reputasi Auditor \\
\hline & \\
\hline
\end{tabular}

Hipotesis 5 dalam penelitian ini bertujuan untuk mendukung adanya perbedaan pengaruh opini going concern, pergantian manajemen, kesulitan keuangan, dan reputasi auditor pada auditor switching antara perusahaan berukuran besar, sedang, dan kecil. Alat analisis statistik yang digunakan adalah uji beda koefisien regresian (Jogiyanto, 2004:185). Sebelum melaksanakan uji beda koefisien regresian, terlebih dahulu dilakukan uji regresi logistik dari ketiga kategori ukuran perusahaan. Pengujian regresi logistik untuk perusahaan yang dikategorikan ukuran besar, sedang, dan kecil bertujuan untuk memperoleh nilai koefisien regresi masing-masing persamaan. Setelah mengetahui nilai koefisien persamaan tersebut kemudian tahapan analisis selanjutnya adalah melakukan uji beda terhadap nilai koefisien sebagai dasar pembuktian Hipotesis 5.

Pengujian didasarkan kepada hasil analisis regresi logistik dari pengaruh berbagai faktor terhadap auditor switching. Hasil pengujian hipotesis tersebut didasarkan kepada uji t yang diperoleh dengan membandingkan antara t-hitung dan t-tabel. Jika hasil uji t tidak signifikan (t-hitung lebih kecil dibandingkan t-tabel) ini berarti bahwa tidak terdapat perbedaan pengaruh opini going concern, 
pergantian manajemen, kesulitan keuangan, dan reputasi auditor pada auditor switching antara perusahaan berukuran besar, sedang, dan kecil. Demikian sebaliknya. Model uji beda koefisien regresi yang digunakan adalah sebagai berikut:

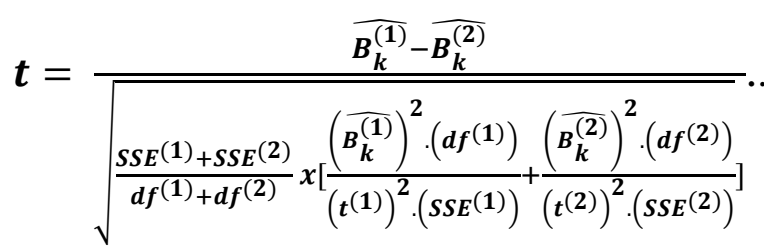

Keterangan:

$\mathrm{B}_{\mathrm{k}} \quad$ : Koefisien regresi variabel independen $\left(\mathrm{X}_{1}, \mathrm{X}_{2}, \mathrm{X}_{3}\right.$, dan $\left.\mathrm{X}_{4}\right)$

SSE : sum of the squared error of regression

df : degree of freedom; $\mathrm{t}=t$-statistic

\section{HASIL DAN PEMBAHASAN}

Data penelitian ini diperoleh dengan mengunduh laporan keuangan auditan perusahaan yang terdaftar di BEI tahun 2013-2015. Tahap pemilihan sampel yang telah dilakukan, disajikan dalam Tabel 1.

Tabel 1

Proses Seleksi Sampel Penelitian

\begin{tabular}{|c|c|c|c|c|c|}
\hline \multirow{2}{*}{ Kriteria } & \multirow{2}{*}{ Keterangan } & \multicolumn{3}{|c|}{ Tahun } & \multirow{2}{*}{ Observas } \\
\hline & & 2013 & 2014 & 2015 & \\
\hline 1. & $\begin{array}{l}\text { Perusahaan yang Listing di Bursa Efek } \\
\text { Indonesia }\end{array}$ & 318 & 345 & 358 & 1.224 \\
\hline 2. & $\begin{array}{l}\text { Perusahaan non manufaktur yang listing } \\
\text { di Bursa Efek Indonesia }\end{array}$ & $(78)$ & $(93)$ & $(104)$ & $(275)$ \\
\hline 3. & Perusahaan yang tidak konsisten listing & $(86)$ & $(95)$ & $(96)$ & $(277)$ \\
\hline 4. & $\begin{array}{l}\text { Laporan Keuangan tidak dapat diakses } \\
\text { selama periode amatan }(2013-2015)\end{array}$ & $(28)$ & $(31)$ & $(32)$ & $(91)$ \\
\hline 5. & Jumlah Pengamatan & 126 & 126 & 126 & 378 \\
\hline
\end{tabular}

Berdasarkan data sekunder yang ditabulasi sesuai dengan kriteria purposive sampling yang sudah ditentukan di awal yang sudah ditentukan, jumlah sampel 
yang diperoleh sebanyak126 perusahaan dengan lama pengamatan selama tiga tahun dan menghasilkan pengamatan sebanyak 378.

Hasil pengujian statistik deskriptif ditujukan untuk mengetahui karakteristik distribusi data atau gambaran fenomena. Berdasarkan Tabel 2 statistik deskriptif yang ditunjukkan adalah nilai maksimum, rata-rata, nilai minimum dan standar deviasi, serta $\mathrm{N}$ merupakan banyaknya sampel yang diolah.

\section{Tabel 2}

\section{Hasil Statistik Deskriptif}

\begin{tabular}{lcrrrr}
\hline Variabel & N & \multicolumn{1}{c}{ Minimum } & Maximum & Mean & \multicolumn{1}{c}{ Std. Deviation } \\
\hline SWITCH & 378 & 0,000 & 1,000 & 0,201 & 0,401 \\
OGC & 378 & 0,000 & 1,000 & 0,256 & 0,437 \\
PM & 378 & 0,000 & 1,000 & 0,169 & 0,375 \\
KK & 378 & $-0,080$ & 9,570 & 0,923 & 1,601 \\
RA & 378 & 0,000 & 1,000 & 0,383 & 0,486 \\
\hline
\end{tabular}

Sumber: Lampiran 1

Variabel auditor switching (Y) memiliki nilai minimum sebesar 0 dan nilai maksimum sebesar 1. Nilai rata-rata auditor switching sebesar 0,201persen yang menunjukkan bahwa sampel penelitian yang melakukan auditor switching sebanyak 20,1 persen sedangkan 79,9 persen sampel penelitian lainnya tidak melakukan auditor switching. Nilai standar deviasi sebesar 0,401 yang menunjukkan bahwa terdapat penyimpangan nilai sebesar 40,1 persen dari nilai rata-rata.

Variabel Opini Going Concern $\left(\mathrm{X}_{1}\right)$ memiliki nilai minimum sebesar 0 dan nilai maksimum sebesar 1. Nilai rata-rata Opini Going Concern sebesar 0,256yang menunjukkan bahwa sampel penelitian yang menerima opini going concern sebanyak 25,60 persen sedangkan 74,40 persen sampel penelitian tidak menerima opini going concern dari auditor. Nilai standar deviasi sebesar0,437 
yang menunjukkan bahwa terdapat penyimpangan nilai sebesar 43,73 persen dari nilai rata-rata.

Variabel Pergantian Manajemen $\left(\mathrm{X}_{2}\right)$ memiliki nilai minimum sebesar 0 dan nilai maksimum sebesar 1 Nilai rata-rata sebesar 0,169 menunjukan bahwa rata-rata sampel penelitian yang melakukan pergantian manajemen sebesar 16,9 persen sedangkan 73,1 persen sampel tidak melakukan pergantian manajemen selama periode amatan. Nilai standar deviasi sebesar0,375 yang menunjukkan bahwa terdapat penyimpangan nilai sebesar 37,5 persen dari nilai rata-rata.

Variabel kesulitan keuangan $\left(\mathrm{X}_{3}\right)$ memiliki nilai minimum sebesar $-0,08$ dan nilai maksimum sebesar 9,57. Nilai rata-rata sebesar 0,923 menunjukan bahwa rata-rata perusahaan berada dalam kondisi kemungkinan terjadinya kesulitan keuangan. Nilai 0,923 berada di bawah 1,81 yang artinya perusahaan tergolong dalam kesulitan keuangan. Nilai standar deviasi sebesar1,601 yang menunjukkan bahwa terdapat penyimpangan nilai sebesar 1,6 persen dari nilai rata-rata.

Variabel reputasi auditor $\left(\mathrm{X}_{4}\right)$ memiliki nilai minimum sebesar 0 dan nilai maksimum sebesar 1. Nilai rata-rata sebesar 0,3836 menunjukan bahwa 38,36 persen perusahaan yang menjadi sampel penelitian diaudit oleh KAP non BIG 4 sedangkan 61,64 persen diaudit oleh auditor yang terafiliasi dengan KAP BIG 4. Nilai standar deviasi sebesar0,48691 yang menunjukkan bahwa terdapat nilai yang menyimpang sebesar 48,69 persen dari nilai rata-rata.

Analisis regresi logistik digunakan dengan alasan bahwa variabel terikat dalam penelitian ini bersifat dummy atau kategorikal, dalam penelitian ini variabel 
yang diukur dengan kategori yaitu melakukan auditor switching atau tidak melakukan auditor switching. Tahapan-tahapan dalam uji regresi logistik sebagai berikut.

1) Menilai kelayakan model regresi

Tabel 3

Hasil Uji Hosmer and Lemeshow Test

\begin{tabular}{|c|c|c|c|}
\hline Step & Chi-Square & Df & Sig. \\
\hline 1 & 13,030 & 8 & 0,111 \\
\hline
\end{tabular}

Dari tabel pengujianHosmer and Lemeshow dapat disimpulkan nilai statistik uji Homemer and Lemeshowmemiliki nilai sebesar 0,111 yang lebih besar dari 0,05 maka model disimpulkan dapat memprediksi nilai observasinya dan tidak bias dalam prediksi nilai regresi.

2) Menilai keseluruhan mode regresi (Overall model fit)

Tabel 4

Perbandingan -2Log Likelihood Awal dan Akhir

\begin{tabular}{cc}
\hline Keterangan & -2 Log Likelihood \\
\hline-2 Log Likelihood (-2LogL) pada awal & 378,886 \\
-2 Log Likelihood (-2LogL) pada akhir & 376,635
\end{tabular}
Sumber: Lampiran 2

Nilai -2LogL awal sebesar 378,886 dan nilai -2LogL akhir sebesar 376,635, penurunan nilai $-2 \log \mathrm{L}$ ini mendeskripsikan model regresi yang baik atau dengan kata lain model yang dihipotesiskan sesuai dengan data yang telah diobservasi.

3) Koefisien determinasi (Nagelkerke's $R$ Square) 
Tabel 5

Model Summary

\begin{tabular}{lrrr}
\hline Step & $\begin{array}{c}-2 \text { Log } \\
\text { likelihood }\end{array}$ & $\begin{array}{c}\text { Cox \& Snell R } \\
\text { Square }\end{array}$ & \multicolumn{2}{c}{ Nagelkerke R Square } \\
\hline 1 & $361,852^{\mathrm{a}}$ & 0,038 & 0,061 \\
\hline Sumber: Lampiran 2 & & &
\end{tabular}

Berdasarkan Tabel 5 menunjukan bahwa Nagelkerke $R$ Square sebesar 0,061. Hal ini berarti variabel bebas yang digunakan dalam penelitian ini yaitu opini audit going concern, pergantian manajemen, kesulitan keuangan dan reputasi auditor mempengaruhi variabel terikat auditor switching sebesar $6,1 \%$ sedangkan $93,9 \%$ dipengaruhi oleh variabel lain yang tidak dimasukan dalam penelitian ini.

4) Uji multikoleniaritas

\section{Tabel 6}

\section{Hasil Uji Multikolinearitas}

\begin{tabular}{|c|c|c|c|c|c|c|}
\hline & & Constant & $\mathrm{X}_{1}$ & $\mathrm{X}_{2}$ & $\mathrm{X}_{3}$ & $\mathrm{X}_{4}$ \\
\hline Step & Constant & 1,000 & $-0,428$ & $-0,192$ & 0,348 & $-0,395$ \\
\hline \multirow[t]{4}{*}{1} & $\mathrm{X} 1$ & $-0,428$ & 1,000 & 0,045 & 0,045 & 0,010 \\
\hline & $\mathrm{X} 2$ & $-0,192$ & 0,045 & 1,000 & $-0,008$ & $-0,161$ \\
\hline & X3 & 0,348 & 0,045 & $-0,008$ & 1,000 & 0,012 \\
\hline & $\mathrm{X} 4$ & $-0,395$ & 0,010 & $-0,161$ & 0,012 & 1,000 \\
\hline
\end{tabular}

Sumber: Lampiran 2

Keterangan :

$\mathrm{X}_{1} \quad$ : Opini Going Concern

$\mathrm{X}_{2} \quad$ : Pergantian Manajemen

$\mathrm{X}_{3}$ : Kesulitan Keuangan

$\mathrm{X}_{4} \quad$ : Reputasi Auditor

Hasil penelitian menunjukkan nilai koefisien korelasi antara variabel tidak lebih besar dari 0,9 maka dapat disimpulkan bahwa tidak terdapat gejala multikolinearitas antara variabel bebas.

5) Matriks klasifikasi 
ISSN : 2337-3067

E-Jurnal Ekonomi dan Bisnis Universitas Udayana 7.2 (2018): 397-428

Tabel 7

Matriks Klasifikasi

\begin{tabular}{lccccr}
\hline & & \multicolumn{3}{c}{ Predicted } \\
Observed & & SWITCH & Percentage \\
\hline Step 1 & SWITCH & 0,00 & Dummy 0 & Dummy 1 & Correct \\
\hline & & 303 & 0 & 100,0 \\
& Overall Percentage & 75 & 0 & 0,0 \\
& 1,00 & & & & 80,2 \\
\hline
\end{tabular}

Sumber: Lampiran 2

Tabel 7 menunjukkan kekuatan prediksi dari model regresi untuk memprediksi kemungkinan perusahaan melakukan auditor switching dan tidak melakukan auditor switching adalah masing-masing sebesar 80,2 persen. Hal ini menunjukkan bahwa dengan model regresi tersebut, terdapat sebanyak 303 perusahaan yang tidak melakukan auditor switching dan 75 perusahaan yang melakukan auditor switching.

6) Model regresi logistik terbentuk

Tabel 8

Variables in the Equation

\begin{tabular}{clrrrrrr}
\hline & & \multicolumn{1}{c}{ B } & S.E. & Wald & df & Sig. & $\operatorname{Exp}($ B $)$ \\
\hline Step & OGC & 0,229 & 0,293 & 0,610 & & 0,435 & 1,257 \\
$1^{\text {a }}$ & PM & $-0,633$ & 0,433 & 2,135 & 1 & 0,144 & 0,531 \\
& KK & 0,220 & 0,111 & 3,955 & 1 & 0,047 & 1,247 \\
& RA & $-0,628$ & 0,297 & 4,491 & 1 & 0,034 & 0,533 \\
& Constant & $-0,994$ & 0,192 & 26,917 & 1 & 0,000 & 0,370 \\
\hline
\end{tabular}

Sumber: Lampiran 2

Berdasarkan Tabel 8 diperoleh persamaan regresi sebagai berikut:

$$
\operatorname{Ln} \frac{S W I T C H}{1-S W I T C H}=-0,994+0,2290 G C-0,633 P M+0,220 K K-0,628 R A+\varepsilon
$$

Berdasarkan persamaan tersebut konstanta memiliki nilai sebesar -0,994. Angka tersebut mempunyai arti bahwa jika variabel yaitu opini audit going concern, pergantian manajemen, kesulitan keuangan dan reputasi 
auditor bernilai konstan maka kemungkinan terjadinya auditor switching menurun 99,4 persen.

Persamaan koefisien regresi logistik dari opini going concern sebesar 0,229 mempunyai arti bahwa, apabila perusahaan memperoleh opini going concern maka terdapat kemungkinan besar terjadi auditor switching sebesar 22,9 persen dengan asumsi faktor lainya konstan. Begitu juga sebaliknya apabila perusahaan tidak memperoleh opini going concern maka terdapat kemungkinan kecil terjadi auditor switching dengan asumsi faktor lainya konstan.

Persamaan koefisien regresi logistik dari pergantian manajemen sebesar -0,633 mempunyai arti bahwa apabila pergantian manajemen tinggi, maka kemungkinan terjadinya auditor switching semakin rendah dengan asumsi faktor lainya konstan. Begitu juga sebaliknya, jika pergantian manajemen rendah, maka kemungkinan terjadinya auditor switching semakin tinggi dengan asumsi faktor lainya konstan.

Persamaan koefisien regresi logistik dari kesulitan keuangan sebesar-0,220 mempunyai arti bahwa apabila perusahaan berada dalam kondisi kesulitan keuangan, maka kemungkinan terjadinya auditor switching semakin tinggi dengan asumsi faktor lainya konstan. Begitu juga sebaliknya, apabila perusahaan tidak berada dalam kondisi kesulitan keuangan, maka kemungkinan terjadinya auditor switching semakin rendah dengan asumsi faktor lainya konstan. 
Persamaan koefisien regresi logistik dari reputasi auditor sebesar -0,628 mempunyai arti bahwa apabila perusahaan bekerja sama dengan KAP Big 4 untuk melakukan audit laporan keuangan maka kemungkinan terjadinya auditor switching semakin rendah dengan asumsi faktor lainya konstan. Begitu juga sebaliknya, apabila perusahaan tidak bekerja sama dengan KAP Big 4, maka kemungkinan terjadinya auditor switching semakin tinggi dengan asumsi faktor lainya konstan.

Hasil uji regresi logistik menunjukan nilai koefisien positif sebesar 0,229 dengan tingkat signifikansi sebesar 0,435 yang lebih tinggi dari $\alpha=5 \%(0,435>$ 0,05). Hasil ini diinterpretasikan bahwa opin igoing concern tidak memiliki pengaruh terhadap auditor switching. Hal ini dapat terjadi karena perusahaan yang tidak menerima opini going concern selama periode pengamatan berjumlah cukup banyak. Hasil penelitian ini tidak konsisten dengan penelitian yang dilakukan oleh Santi Rahayu (2012), Carcello dan Niel (2003), Kumalawati (2012) dan Diyanti (2010) yang menemukan bahwa opini audit going concern berpengaruh pada auditor switching. Hasil penelirian tidak sependapat dengan kesimpulan yang ditemukan oleh Sinarwati (2009) yang menyimpulkan bahwa opini going concern tidak berpengaruh terhadap auditor switching.

Opini going concern adalah opini wajar tanpa pengecualian yang diberikan jika terdapat potensi terkait dengan kondisi atau peristiwa yang berimplikasi terhadap kelangsungan hidup operasional perusahaan terkait situasi tersebut tersebut terdapat kesangsian auditor, untuk mengatasi kondisi tersebut, manajemen telah memiliki rencana jangka pendek serta jangka panjang, sehingga 
rencana tersebut menurut auditor efektif untuk dijalanklan. Perusahaan yang merima opini going concern tidak selalu melakukan auditor switching karena adanya harapan dari pihak perusahaan bahwa rencana-rencana yang telah disusun oleh manajemen untuk melakukan evaluasi yang menyebabkan keraguan dari pihak auditor, sehuingga auditor tidak berencana untuk menerbitkan kembali opini going concern di tahun selanjutnya (Mahantara 2013). Sampel pada penelitian ini yang menerima opini going concern selama periode pengamatan sejumlah 281 amatan atau sebesar 74,3 persen sedangkan amatan yang menerima opini going concern sejumlah 97 amatan atau sebesar 25,7\%. Jumlah perusahaan yang menerima opini going concern menjadi dasar yang menunjukkan bahwa tidak banyak perusahaan yang memiliki kekhawatiran terkait dengan perolehan opini audit going concern.

Hasil uji regresi logistik menunjukan nilai koefisien negatif sebesar -0,633 dengan tingkat signifikansi sebesar 0,144 yang lebih besar dari $\alpha=5 \%(0,144>$ 0,05). Hal ini diinterpretasikan bahwa pergantian manajemen tidak memiliki pengaruh pada auditor switching. Hasil penelitian ini tidak konsisten dengan hasil penelitian yang dilakukan oleh Wijayani dan Januarti (2011), Damayanti dan Sudarma (2008), Nagi (2005), Sentosa dan Wedari (2007) dan McKeown et al. (1991) yang menyatakan bahwa perusahaan melakukan auditor switching pada perusahaan yang mengalami pergantian manajemen. Akan tetapi hasil penelitian tersebut berbeda dengan penelitian yang dilakukan oleh Damayanti dan Sudarma (2006) yang menemukan pergantian manajemen tidak berpengaruh signifikan pada auditor switching. Perusahaan yang mengalami pergantian manajemen 
diindikasikan masih dapat berdiskusi dengan auditor sebelumnya dengan dasar pemikiran bahwa auditor terdahulu memahami kondisi keuangan perusahaan, prospek perusahaan serta dapat membantu meminimalkan resiko perusahaan di masa mendatang. Manajemen yang baru masih memerlukan saran serta tanggapan dari auditor sebelumnya dengan tujuan agar dapat mengambil keputusan sesuai dengan kondisi keuangan perusahaan. Auditor sebelumnya dianggap memahami perusahaan jauh lebih baik karena sudah memiliki ikatan dengan perusahaan dari periode sebelumnya. Mengganti auditor pada saat pergantian manajemen dipandang akan menimbulkan resiko karena manajemen yang baru membutuhkan waktu yang cukup lama untuk mengetahui lingkungan perusahaan.

Hasil uji regresi logistik menunjukan nilai koefisien negatif sebesar 0,220 dengan tingkat signifikansi sebesar 0,047 yang lebih rendah dari $\alpha=5 \%$ $(0,047<0,05)$. Hasil penelitian konsisten dengan penelitian yang ditemukan oleh Damayanti dan Sudarma (2008),Sinarwati (2011) dan Nasser et al. (2006). Hal ini diinterpretasikan bahwa variabel kesulitan keuangan memiliki pengaruh positif pada auditor switching. Kebangkrutan merupakan kondisi dimana perusahaan tidak mampu lagi untuk memenuhi kewajibannya. Schwartz et. al. (1995) menyatakan perusahaan yang mengalami kesulitan keuangan terancam bangkrut cenderung untuk berganti KAP, karena tidak mampu membayar fee audit. Schwartz et. al (1985) menyebutkan ada dorongan kuat untuk berganti auditor pada perusahaan yang terancam bangkrut. Selain itu perusahaan yang sedang mengalami kesulitan keuangan cenderung berganti auditor karena auditor 
dianggap tidak dapat mencegah terjadinya kesulitan keuangan pada perusahaan. Perusahaan dengan kondisi kesulitan keuangan mengganti auditornya dengan dasar pemikiran bahwa auditor yang baru diharapkan dapat memberikan saran serta tanggapan yang lebih baik yang dapat memperbaiki kondisi keuangan perusahaan dibandingkan dengan auditor yang lama.

Hasil uji regresi logistik menunjukan nilai koefisien negatif sebesar -0,628 dengan tingkat signifikansi sebesar 0,034 yang lebih rendah dari $\alpha=5 \%$ $(0,034<0,05)$. Hal ini diinterpretasikan bahwa variabel reputasi auditor memiliki pengaruh negatif pada auditor switching. Hasil penelitian sesuai dengan penelitian yang dilakukan oleh Fillani dan Yenni (2012) yang menyimpulkan bahwa reputasi auditor memiliki pengaruh negatif terhadap auditor switching. Halim (1997) menyatakan bahwa perusahaan berupaya menemukan KAP dengan kredibilitas yang sudah diakui untuk melakukan peningkatan nilai objektivitas dari laporan keuangan dimata pengguna laporan keuangan tersebut. Perusahaan dengan auditor yang tidak bereputasi cenderung mengganti auditornya dengan alasan bahwa auditor big 4 dapat memberikan saran yang lebih baik karena pengalamannya. Crasswell et. al (1998) menyatakan, klien atau calon investor biasanya berpandangan bahwa auditor yang berafiliasi dengan KAP besar mempunyai hasil opini yang lebih objektif dan berkualitas yang lebih tinggi karena auditor tersebut memiliki komponen yang memadai untuk dapat dikaitkan dengan kualitas seperti pelatihan, pengakuan international, serta adanya peer review. Hasil penelitian konsisten dengan penelitian yang ditemukan oleh Fillani dan Yenni (2012)yang 
menemukan pengaruh yang signifikan dari reputasi auditor terhadap pergantian KAP.

7) Uji Beda Koefisien Regresi

Hasil uji beda koefisien regresi untuk menentukan apakah terdapat perbedaan antara variabel opini audit going concern (OGC), pergantian manajemen $(\mathrm{PM})$, kesulitan keuangan $(\mathrm{KK})$ dan reputasi auditor (RA) terhadap auditor switching (SWITCH) pada perusahaan berskala besar, sedang dan kecil.

Tabel 10 menunjukkan bahwa perbedaan pengaruh variabel yang mempengaruhi auditor switching terdapat pada perusahaan yang berkategori besar dan kecil yang ditunjukkan dengan t-hitung lebih kecil daripada t tabel $(-1,861<-1,657)$ sehingga terdapat perbedaan yang signifikan antara perusahaan yang berkategori besar dan kecil.

Tabel 10

Uji Beda Koefisien Regresi

\begin{tabular}{cccccrrr}
\hline Ket. & $\beta 1$ & $\beta 2$ & SSE1 & \multicolumn{1}{c}{ SSE2 } & \multicolumn{1}{l}{ t1 } & \multicolumn{1}{c}{ t2 } & \multicolumn{2}{c}{ t-hitung } \\
\hline K-S & $-1,292$ & $-1,077$ & 0,461 & 0,433 & 7,868 & 6,186 & $-0,897$ \\
K-B & $-1,292$ & $-0,998$ & 0,461 & 0,236 & 7,868 & 17,936 & $-1,861 * *$ \\
S-B & $-1,077$ & $-0,998$ & 0,433 & 0,236 & 6,186 & 17,936 & $-0,473$ \\
\hline
\end{tabular}

Keterangan:

$\mathrm{B}_{1,2} \quad$ : Koefisien regresi variabel independen

$\mathrm{SSE}_{1,2} \quad$ : sum of the squared error of regression

$t \quad: t$-statistic

** $\quad:$ signifikan

Pengujian uji koefisien menunjukkan bahwa tidak terdapat perbedaan antara perusahaan skala besar dan sedang serta perusahan skala sedang dan kecil dengan nilai t-hitung sebesar $-0,897$ dan $-0,473$. Namun, hasil uji koefisien regresi perusahaan besar dan kecil menunjukan bahwa nilai koefisien negatif sebesar 
-1,861 yang lebih rendah dari t-hitung sebesar -1,657. Hasil pengujian menunjukkan bahwa terdapat perbedaan pengaruh opini going concern, pergantian manajemen, kesulitan keuangan, dan reputasi auditor pada auditor switching antara perusahaan berukuran besar dan kecil. Hasil penelitian mengkonfirmasi Effect Size Theory. Effect Size Theory menjelaskan bahwa perbedaan ukuran perusahaan dapat menjadi pembeda pengaruh antar variabel yang mempengaruhi perusahaan. Effect Size dalam penelitian ini dibagi kedalam tiga kategori yaitu ukuran besar, sedang dan kecil. Hasil penelitian konsisten dengan temuan dari Ramadhany (2004) dan Santosa dan Wedari (2007). Perusahaan dengan ukuran yang lebih besar memiliki akses yang lebih mudah dalam memperoleh sumber pendanaan, sehingga dalam mendapatkan bantuan pendanaan dari kreditur cenderung lebih mudah karena perusahaan dengan ukuran besar memperoleh peluang yang relatif lebih besar dalam bertahan di industri (Fitria, 2014).

Perusahaan besar memiliki fasilitas atau peluang yang lebih besar dibandingkan perusahaan kecil untuk memperpanjang kontraknya dengan auditor yang sebelumnya (Carcello dan Neal, 2003). Hasil penelitian juga diperkuat dengan kesimpulan yang ditemukan oleh Monica (2016) yang menyatakan, auditor yang berafiliasi dengan KAP besar mempunyai kredibilitas yang baik sehingga menyebabkan kualitas mengenai hasil auditnya merefleksikan situasi perusahaan. Ukuran perusahaan dengan skala yang lebih kecil cenderung berupaya untuk mengganti KAP dan berpindah menunjuk KAP big 4 ke KAP non big 4 yang kemudian melakukan perikatan (Suryandari, 2012). 


\section{SIMPULAN DAN SARAN}

Opini Going Concern tidak berpengaruh terhadap Auditor Switching pada perusahaan yang terdaftar di Bursa Efek Indonesia tahun 2013-2015. Pergantian Manajemen tidak berpengaruh terhadap Auditor Switching pada perusahaan yang terdaftar di Bursa Efek Indonesia tahun 2013-2015. Kesulitan Keuangan berpengaruh positif terhadap Auditor Switching pada perusahaan yang terdaftar di Bursa Efek Indonesia 2013-2015. Reputasi Auditor berpengaruh negatif terhadap Auditor Switching pada perusahaan yang terdaftar di Bursa Efek Indonesia 2013-2015. Terdapat perbedaan pengaruh Opini Going Concern, Pergantian Manajemen, Kesulitan Keuangan, dan Reputasi Auditor pada Auditor Switching antara perusahaan berukuran besar dan kecil yang terdaftar di Bursa Efek Indonesia 2013-2015.

Penelitian selanjutnya, diharapkan dapat menyempurnakan penelitian ini dengan mempertimbangkan variabel lain yang diperkirakan dapat mempengaruhi auditor switching pada perusahaan go public. Penambahan variabel didasarkan pada pengaruh variabel independen dalam penelitian ini terhadap auditor switching masih rendah. Variabel yang disarankan dapat berupa fee audit, opini audit sebelumnya dan variabel lain yang diduga dapat meningkatkan kemungkinan terjadinya auditor switching.

Bagi perusahaan diharapkan agar berhati-hati dalam melakukan auditor switching. Perusahaan dalam hal ini para pengambil keputusan (shareholders) dapat melihat motivasi dari manajemen, apakah kebijakan dimotivasi oleh 
keinginan manajemen atau kebijakan tersebut dilakukan atas dasar kesulitan keuangan perusahaan, serta melihat reputasi auditor dalam memilih KAP sehingga menimbulkan kepercayaan para investor pada perusahaan untuk menanamkan modalnya pada perusahaan tersebut.

\section{REFERENSI}

Alexander, Ramadhany, 2004. Analisis Faktor-Faktor yang Mempengaruhi Penerimaan Opini Going Concern pada Perusahaan yang Terdaftar di BEJ. (tesis). Semarang: Magister Akuntansi, Universitas Diponegoro.

Ardana, Komang, Ni Wayan Mujiati dan Anak Agung Ayu Sriathi. 2008. Perilaku Keorganisasian, Yogyakarta, Graha Ilmu.

Carcello, J.V dan T.L. Neal 2003. Audit Committee Characteristics and Auditor Dismissal following New Going Concern Reports. The Accounting Review. Vol. 78, No. 1, January 2003.

Chow, C.W., and Rice, S.J. 1982. Qualified Audit Opinions and Auditor Switching. The Accounting Review. Vol. LVII No. 2. Pp 326-335

Citron, D.B., Manalis. G. 2001. The International Firms as New Entrants to The Staturory Audit Market: An Empirical Analysis of Auditor Selection in Greece, 1993 to 1997. The European Accounting Review. Vol. 10. No.3.pp. 439-459.

Craswell, AT 1998. The Assosiation between qualified opinion and auditor switches. Accounting and Business Research. $19^{\text {th }}$.

Damayanti, Sudarma 2006. "Faktor-Faktor Yang Mempengaruhi Perusahaan Berpindah Kantor Akuntan Publik" (tesis), Malang: Universitas Brawijaya.

Diyanti, Putri. 2010. Opini Audit Going concern dan Faktor-Faktor yang Mempengaruhi: Studi Pada Perusahaan Manufaktur di Bursa Efek Indonesia (Tesis). Denpasar: Universitas Udayana

Fitria Octari Hidayanti, 2014. "Reputasi Auditor, Ukuran Perusahaan Dan Opini Audit Tahun Sebelumnya Dalam Memprediksi Pemberian Opini Audit Going Concern”Accounting Analysis Journal. AAJ 3 (4) (2014). Fakultas Ekonomi, Universitas Semarang, Indonesia.

Gunady, Filani dan Yenni Mangoting, 2013. "Faktor-Faktor yang Mempengaruhi Keputusan Perusahaan Manufaktur yang Terdaftar di BEI Tahun 2008-2012 
Melakukan Pergantian Kantor Akuntan Publik". Tax \& Accounting Review, Vol. 3, No.2.

Halim, A., 1997, Dasar-dasar Audit Laporan Keuangan, Unit Penerbit \& Percetakan (UPP) AMP YKPN: Yogyakarta.

Hana, 2012. "Faktor-Faktor Yang Mempengaruhi Perusahaan Manufaktur Terdaftar Di BEI Melakukan Voluntary Auditor Switching" Fak.Ekonomi dan Bisnis” Accounting Analysis Journal. Semarang: Universitas Diponegoro.

Jensen, M.C. 1993. Presidential Address: The Modern Industrial Revolution, Exit, and the Failure of Internal Control system. Journal of France. Vol. 48. Pp.. 830881.

Jensen, M.C, and William H. M. 1976. Revolution, Exit and the Failure of Internal Control System. Journal of financial Economics. Vol. 3. Pp. 82-136

Jansen, M.C. 1986. Agency Costs of Free Cash Flow, Corporate Finance, and Takeovers. AEA Paper and Proceedings. Vol. 76 No.2.

Kumalawati, Lely. 2012. "Faktor-Faktor yang Mempengaruhi Opini Going Concern: Studi Empiris pada Perusahaan Manufaktur yang Terdapat di Bursa Efek Indonesia”. Jurnal Akuntansi dan Ekonomi Bisnis.Vol.1.

Mahantara, AA. Gde. 2013. Faktor-Faktor Yang Memengaruhi Pergantian Kantor Akuntan Publik Pada Perusahaan Yang Terdaftar Di Bursa Efek Indonesia. (tesis). Universitas Udayana. Bali.

McKeown, J. Mutchler, J dan Hopwood W. 1991. "Towards an Explanation of Auditor Failure to modify the Audit Opinion of Bankrupt Companies". Auditing: A Journal Practice \& Theory. Supplement. 1-13.

Melumad dan Ziv, 1997. Market Reaction to Auditor Switching From Big Four to Smaller Accounting Firm. Journal of Accounting \& Public Policy.

Martina Putri Wijayanti. (2010). "Analisis Hubungan Auditor-Klien: FaktorFaktor yang Mempengaruhi Auditor Switching di Indonesia". Semarang: Universitas Diponegoro.

Mohamed, Diana Mostafa. 2010. The Impact of the Auditor Rotationon the Audit Quality: A Field Study From Egypt. www.ssrn.co.id

Monica, 2016. "Faktor-Faktor Yang Mempengaruhi Opini Audit Going Concern”. E-Jurnal Akuntansi Universitas Udayana. Vol.14.1 Januari 2016: 451481.

Nasser, Wahid, Nazri, dan Hudaib. 2006. Auditor-Client Relationship: The Case of Audit tenure and Auditor Switching in Malaysia. Managerial Auditing Journal, Vol. 21. 
Ni Kadek Sinarwati. (2010). "Mengapa Perusahaan Manufaktur yang Terdaftar di BEI Melakukan Pergantian Kantor Akuntan Publik?'. Simposium Nasional Akuntansi XIII.

Ramadhany, Alexander, 2004. Analisis Faktor-Faktor yang Mempengaruhi Penerimaan Opini Going Concern pada Perusahaan yang Terdaftar di BEJ. (tesis). Semarang: Magister Akuntansi, Universitas Diponegoro.

Santi Rahayu, 2012. Moderasi Reputasi Auditor Terhadap Faktor-Faktor Yang Mempengaruhi Auditor Switching Pada Perusahaan Industri Manufaktur Yang Terdaftar Di BEI Pada Tahun 2006-2010. (tesis). Jakarta: Program Pascasarjana Universitas Esa Unggul.

Santosa, Arga F. Dan Linda K. Wedari. 2007. "Analisis Faktor-Faktor yang mempengaruhi Kecenderungan Penerimaan Opini Audit Going Concern". JAAI, Vol.11 No.3. pp: 141-158

Schwartz, K.B. dan B.S. Soo. 1995. An Analysis of Firm 8-K Disclousure of Auditor Changes by Firms Approaching Bankruptcy, Auditing: A Journal of Practice Theory, Vol. 14. No. 1, Spring 1995, 125-135.

Standar Audi 700. Perumusan suatu Opini dan Pelaporan atas Laporan Keuangan.

Sugiyono. 2015. Metode Penelitian dan Pengembangan: Research and Development: Untuk Bidang: Pendidikan, Manajemen, Sosial, Teknik . Bandung: Alfabeta.

Sumarsono, HM. Sonny, 2004, Metode Riset Sumber Daya Manusia Jember: Graha Ilmu.

Suryandari, Ayu. 2012. Analisis Faktor-faktor yang Mempengaruhi Pergantian KAP Pada Perusahaan Manufaktur yang Terdaftar di BEI. (tesis). Denpasar:Program Pasca Sarjana, Universitas Udayana.

Tandirerung, YT. 2006. Kajian Tentang Independensi Auditor Dari Aspek Penunjukan KAP dan Pembayaran Fee Audit Secara Langsung Oleh Klien. (tesis). Malang: Fakultas Ekonomi, Universitas Brawijaya. 